\title{
PHOTOSYNTHESIS, PHOTOCHEMICAL EFFICIENCY AND GROWTH OF WEST INDIAN CHERRY CULTIVATED WITH SALINE WATERS AND NITROGEN FERTILIZATION
}

\author{
FOTOSSÍNTESE, EFICIÊNCIA FOTOQUÍMICA E CRESCIMENTO DA \\ ACEROLEIRA CULTIVADA COM ÁGUAS SALINAS E ADUBAÇÃO NITROGENADA
}

\author{
Geovani Soares de LIMA ${ }^{1}$; Elysson Marcks Goncalves ANDRADE ${ }^{2}$; Tankpinou Richard \\ KETOUNOU ${ }^{3}$; Vera Lucia Antunes de LIMA ${ }^{4}$; Hans Raj GHEYI ${ }^{5}$; Saulo Soares da SILVA ${ }^{6}$; \\ Lauriane Almeida dos Anjos SOARES ${ }^{7}$ \\ 1. Professor Visitante, Universidade Federal de Campina Grande - UFCG, Unidade Acadêmica de Ciências Agrárias, Pombal, PB, \\ Brasil. geovanisoareslima@gmail.com; 2. Professor, Doutor, Faculdade Santa Maria, Cajazeiras, PB, Brasil; 3. Graduando em \\ Engenharia Agrícola, Unidade Acadêmica de Engenharia Agrícola, UFCG, Campina Grande, PB, Brasil. 4. Professora, Doutora, UFCG, \\ Engenharia Agrícola, UFCG, Campina Grande, PB, Brasil. 5.Professor Visitante, Universidade Federal do Recôncavo da Bahia, Cruz \\ das Almas, BA, Brasil; 6. Doutorando em Engenharia Agrícola, Programa de Pós graduação em Engenharia Agrícola, UFCG, Campina \\ Grande, PB, Brasil; 7. Professora, Doutora, UFCG, Unidade Acadêmica de Ciências Agrárias, Pombal, PB, Brasil.
}

\begin{abstract}
In the semi-arid region of Northeast Brazil, water salinity is one of the main abiotic factors limiting crop growth and development. However, given the water scarcity affecting this region, the use of waters with moderate to high salt contents becomes necessary to irrigate crops. Thus, generating technologies that enable the use of saline waters is an essential alternative to the agricultural development of this region. In this context, this study aimed to evaluate photosynthesis, photochemical efficiency and growth of West Indian cherry, as a function of irrigation with saline waters and nitrogen $(\mathrm{N})$ fertilization, in the postgrafting stage. The experiment was carried out in drainage lysimeters under greenhouse conditions, using a typic eutrophic Regolithic Neosol with sandy loam texture, in the municipality of Campina Grande-PB, Brazil. Treatments consisted of the combination between five levels of electrical conductivity of water - ECw $(0.8$; 1.6; 2.4; 3.2 and $4.0 \mathrm{dS} \mathrm{m}^{-1}$ ) and four $\mathrm{N}$ doses - ND (50; 75; 100 and $125 \mathrm{~g}$ of N plant ${ }^{-1}$ per year), arranged in a randomized block design, with 3 replicates. Gas exchanges, chlorophyll $a$ fluorescence and growth of West Indian cherry were compromised by saline water irrigation, regardless of $\mathrm{N}$ dose. Irrigation with $\mathrm{ECw}$ higher than $0.8 \mathrm{dS} \mathrm{m}{ }^{-1}$ caused damages to the photosystem II reaction centers of West Indian cherry. Nitrogen doses did not mitigate the deleterious effects caused by irrigation water salinity on photosynthesis, photochemical efficiency and growth of West Indian cherry.
\end{abstract}

KEYWORDS: Malpighia emarginata. Saline stress. Nitrogen.

\section{INTRODUCTION}

West Indian cherry (Malpighia emarginata D. C.) is a rustic fruit-bearing shrub, belonging to the Malpighiaceae family. It is native to Tropical America and stands out for its high nutritional value, especially as source of ascorbic acid, vitamin $\mathrm{A}$, iron, calcium and complex B vitamins (thiamine, riboflavin, niacin) and in the field of functional foods. It is consumed both fresh and industrialized, in the form of frozen pulp, juices, ice creams, jellies, syrups, liquors, preserved fruit, among other products (ADRIANO et al., 2011; ESASHIKA et al., 2013).

The areas cultivated with West Indian cherry in Brazil are mainly situated in the Northeast region because the edaphoclimatic conditions are favorable to its exploitation. Bahia, Ceará, Paraíba and Pernambuco stand out as the largest West
Indian cherry producing states (ESASHIKA et al., 2013). In this region, the occurrence of irregular rainfalls, high temperatures and intense evaporation in most of the year makes irrigation a necessary practice to guarantee safe agricultural production. Nevertheless, most of the available water sources (underground and surface) exhibit moderate to high concentration of salts (NOBRE et al., 2011).

Water and/or soil salinity limits photosynthesis, due to stomatal and non-stomatal restrictions, and the functional state of the chloroplast thylakoid membrane, because of the osmotic stress, caused by the reduction in the osmotic potential of the soil solution, and because of the ionic effect caused by water absorption and/or by the excessive accumulation of ions in the plant tissues, which may cause ionic toxicity, nutritional imbalance, or both (NEVES et al., 2009; FREIRE et al., 2014). Nonetheless, the concentrations of salts 
affecting photosynthetic activity, photochemical efficiency and growth of plants vary, and the effects on crops depend on species, cultivar, types of salts, stress intensity and duration, crop and irrigation managements, edaphoclimatic conditions and fertilization (MUNNS; TESTER, 2008).

Despite the socioeconomic relevance of West Indian cherry for the semi-arid region of Northeast Brazil and the importance of developing technologies for its cultivation under saline conditions, few studies have been carried out (GURGEL et al., 2003; GURGEL et al., 2007). In addition, these studies are limited to the use of saline water only during rootstock production. Therefore, new studies are necessary, especially to evaluate the effects of salt stress on the West Indian cherry crop in the post-grafting stage.

Furthermore, one should also consider that the use of saline water in irrigation is conditioned to the tolerance of the crops to salinity and to the practices of irrigation and fertilization managements, which can avoid environmental impacts and consequent damages to the crops (LIMA et al., 2015). Therefore, mineral nutrition through fertilizer management stands out among the main strategies employed to increase crop yield and profitability, and nitrogen is one of the main macronutrients responsible for this increase (CHAVES et al., 2011).

Nitrogen fertilization is an alternative that can mitigate the deleterious effects of saline stress on crops, because this macronutrient performs a structural function, participating in various essential organic compounds, particularly amino acids, proteins, coenzymes, nucleic acids etc., which are able to increase the capacity for osmotic adjustment to salinity and increase the tolerance of crops (SILVA et al., 2008; BARHOUMI et al., 2010).

Given its importance as a component of these compounds, nitrogen is involved in the processes occurring in the protoplasm, enzymatic reactions and in photosynthesis, resulting in the stimulus to growth (EPSTEIN; BLOOM, 2006).

Considering the importance of West Indian cherry and the need of using saline waters in agriculture, this study aimed to evaluate photosynthesis, photochemical efficiency and growth of West Indian cherry, subjected to irrigation with different levels of salinity and nitrogen fertilization, in the post-grafting stage.

\section{MATERIAL AND METHODS}

The experiment was carried out using recepients adapted as drainage lysimeters under greenhouse conditions, at the Center of Technology and Natural Resources of the Federal University of Campina Grande (CTRN/UFCG), located in the municipality of Campina Grande-PB, Brazil ( $7^{\circ} 15^{\prime}$ $18^{\prime \prime} \mathrm{S}, 35^{\circ} 52^{\prime} 28^{\prime \prime} \mathrm{W} ; 550 \mathrm{~m}$ ).

The experimental design was randomized blocks, with three replicates, using a $5 \mathrm{x} 4$ factorial arrangement, and treatments consisted of five levels of irrigation water electrical conductivity - $\mathrm{ECw}$ $\left(0.8 ; 1.6 ; 2.4 ; 3.2\right.$ and $\left.4.0 \mathrm{dS} \mathrm{m}^{-1}\right)$ associated with four nitrogen doses - ND $(50 ; 75 ; 100$ and $125 \mathrm{~g}$ of $\mathrm{N}$ plant $^{-1}$ per year), based on the fertilization recommendation of Cavalcante (2008), $100 \mathrm{~g}$ of $\mathrm{N}$ plant $^{-1}$ per year for the West Indian cherry crop.

Solutions with different $\mathrm{ECw}$ levels were prepared by dissolving the salts $\mathrm{NaCl}, \mathrm{CaCl}_{2} \cdot 2 \mathrm{H}_{2} \mathrm{O}$ and $\mathrm{MgCl}_{2} \cdot 6 \mathrm{H}_{2} \mathrm{O}$, in equivalent proportion of $7: 2: 1$, respectively, in public-supply water $(\mathrm{ECW}=1.40 \mathrm{dS}$ $\mathrm{m}^{-1}$ ) of the municipality of Campina Grande-PB, based on the relationship between $\mathrm{ECW}$ and the concentration of salts $\left(10 * \mathrm{mmol}_{\mathrm{c}} \mathrm{L}^{-1}=\mathrm{ECw} \mathrm{dS} \mathrm{m}^{-}\right.$ ${ }^{1}$ ), according to Richards (1954). The lowest salinity level was obtained by mixing public-supply water with rainwater $\left(\mathrm{ECw}=0.02 \mathrm{dS} \mathrm{m}^{-1}\right)$. The bottom of each lysimeter was connected to a 4-mm-diameter hose, to drain the leachate into a container, in order to evaluate the drained water and determine water consumption by plants. The tip of the drain inside the pot was involved with a nonwoven geotextile (Bidim OP 30) to avoid clogging by soil material.

The lysimeters were filled by a $1-\mathrm{kg}$ layer of crushed stone (size zero), followed by $250 \mathrm{~kg}$ of an eutrophic Regolithic Neosol with sandy loam texture, properly pounded to break up clods, from the rural area of the municipality of Esperança-PB. Its physical and chemical characteristics (Table 1) were determined according to the methodologies proposed by Claessen (1997).

The cultivar 'Junco' was used as rootstock for West Indian cherry. This genetic material has characteristics considered as essential, such as high yield (up to $100 \mathrm{~kg}$ plant $^{-1}$ year $^{-1}$ ), production of red fruits with red-colored skin, higher fruit weight (4 to $5 \mathrm{~g}$ ) and vitamin $\mathrm{C}$ content of $1,000 \mathrm{mg} 100 \mathrm{~g}^{-1}$ of pulp. The scion was the cultivar 'Flor Branca', which has good yield, lower vigor and fruits weighing between 3 to $5 \mathrm{~g}$, on average. Its lowest production occurs in June and July, while its highest production occurs from October to April in the region of Submédio São Francisco (CALGARO; BRAGA, 2012). 
Table 1. Chemical and physical characteristics of the eutrophic Regolithic Neosol used in the experiment.

Chemical characteristics

\begin{tabular}{|c|c|c|c|c|c|c|c|c|c|}
\hline \multirow{2}{*}{$\begin{array}{l}\mathrm{pH}\left(\mathrm{H}_{2} \mathrm{O}\right) \\
(1: 2.5)\end{array}$} & \multirow{2}{*}{$\begin{array}{l}\mathrm{OM} \\
\text { dag kg }^{-1}\end{array}$} & \multirow{2}{*}{$\begin{array}{l}\mathrm{P} \\
\left(\mathrm{mg} \mathrm{kg}^{-1}\right)\end{array}$} & $\mathrm{K}^{+}$ & $\mathrm{Na}^{+}$ & $\mathrm{Ca}^{2+}$ & $\mathrm{Mg}^{2+}$ & $\mathrm{H}^{+}+\mathrm{Al}^{3+}$ & \multirow{2}{*}{$\begin{array}{l}\text { ESP } \\
(\%)\end{array}$} & \multirow{2}{*}{$\begin{array}{l}\text { ECse } \\
\left(\mathrm{dS} \mathrm{m}^{-1}\right)\end{array}$} \\
\hline & & & \multicolumn{5}{|c|}{ 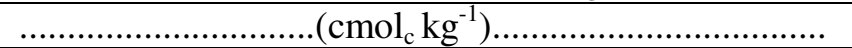 } & & \\
\hline 5.90 & 1.36 & 6.80 & 0.22 & 0.16 & 2.60 & 3.66 & 1.93 & 1.87 & 1.0 \\
\hline \multicolumn{10}{|c|}{ Physical characteristics } \\
\hline \multicolumn{3}{|c|}{ Size fraction $\left(\mathrm{g} \mathrm{kg}^{-1}\right)$} & \multirow{2}{*}{$\begin{array}{l}\text { Textural } \\
\text { class }\end{array}$} & \multicolumn{2}{|c|}{ Water content $(\mathrm{kPa})$} & \multirow[t]{2}{*}{ AW } & \multirow{2}{*}{$\begin{array}{l}\text { Total } \\
\text { porosity } \\
\%\end{array}$} & \multirow[t]{2}{*}{$\mathrm{AD}$} & \multirow[t]{2}{*}{$\mathrm{PD}$} \\
\hline Sand & Silt & Clay & & $\begin{array}{l}33.42 \\
\ldots \ldots \ldots \ldots \ldots . . .\end{array}$ & $\begin{array}{l}1519.5 \\
\text { dag kg }\end{array}$ & & & & \\
\hline 732.90 & 142.10 & 125.00 & SL & 11.98 & 4.32 & 7.66 & 47.74 & $\frac{\mathrm{kg} \mathrm{dm}^{-3}}{1.39}$ & 2.66 \\
\hline
\end{tabular}

Before seedling transplantation, the soil was raised to field capacity, using the respective water of each treatment. After transplanting, irrigation was daily performed and each lysimeter received a water volume sufficient to maintain soil moisture close to field capacity. The irrigation with respective water, was performed daily, and the water volume to be applied in irrigation was determined using Eq. 1:

$V I=\frac{(V a-V d)}{1-L F} \ldots \ldots \ldots \ldots \ldots(1)$

Where: VI = volume of water to be used in thet irrigation event $(\mathrm{mL}) ; \mathrm{Va}=$ volume applied in the previous irrigation event $(\mathrm{mL}) ; \mathrm{Vd}$ volume drained $(\mathrm{mL})$, and $\mathrm{LF}=$ coefficient used to obtain a leaching fraction of $0.10(10 \%)$.

Fertilizations with phosphorus and potassium were performed as recommended by Cavalcante (2008), using the equivalent to $120 \mathrm{~g}$ plant ${ }^{-1}$ of $\mathrm{P}_{2} \mathrm{O}_{5}$ and $\mathrm{K}_{2} \mathrm{O}$. Phosphorus was applied entirely at planting, while nitrogen (according to the dose) and potassium were; split into 12 monthly applications. To meet probable deficiencies of macronutrients, West Indian cherry plants were sprayed every two weeks with a $5 \mathrm{~L}$ of solution containing $1.5 \mathrm{~g} \mathrm{~L}^{-1}$ of Ubyfol [(N $(15 \%) ; \mathrm{P}_{2} \mathrm{O}_{5}$ (15\%); $\mathrm{K}_{2} \mathrm{O}$ (15\%); $\mathrm{Ca}(1 \%) ; \mathrm{Mg}(1.4 \%) ; \mathrm{S}$ (2.7\%); $\mathrm{Zn}(0.5 \%) ; \mathrm{B}(0.05 \%) ; \mathrm{Fe}(0.5 \%) ; \mathrm{Mn}(0.05 \%) ; \mathrm{Cu}$ $(0.5 \%)$; Mo $(0.02 \%)]$. The ubyfol solution was applied via foliar spraying on the adaxial and abaxial surfaces.

Gas exchanges, chlorophyll $a$ fluorescence and growth of West Indian cherry were evaluated at 130 days after transplanting (DAT). Gas exchanges were measured in the intact middle leaf of the intermediate productive branch, based on stomatal conductance - $g_{S}\left(\mathrm{~mol} \quad \mathrm{H}_{2} \mathrm{O} \quad \mathrm{m}^{-2} \mathrm{~s}^{-1}\right), \quad \mathrm{CO}_{2}$ assimilation rate $-A\left(\mu \mathrm{mol} \mathrm{m} \mathrm{m}^{-2}\right)$, transpiration $-E$ $\left(\mathrm{mmol} \mathrm{H} \mathrm{O}_{2}{ }^{-2} \mathrm{~s}^{-1}\right)$ and internal $\mathrm{CO}_{2}$ concentration -
$C i\left(\mu \mathrm{mol} \mathrm{mol}^{-1}\right)$, with a portable infrared gas analyzer (IRGA), model "LCPro+" of ADC BioScientific Ltda.

Chlorophyll $a$ fluorescence was determined by measuring the initial fluorescence (Fo), maximum fluorescence $(\mathrm{Fm})$, variable fluorescence $(\mathrm{Fv})$ and potential quantum efficiency $(\mathrm{Fv} / \mathrm{Fm})$ in leaves previously adapted to the dark using clips for 30 minutes, between 7:00 and 8:00 a.m., in the middle leaf of the intermediate productive branch, was determined using the modulated fluorometer Plant Efficiency Analyzer - PEA II ${ }^{\circledR}$.

Growth was evaluated based on rootstock stem diameter (Diam-RS), stem diameter at the grafting point (Diam-GP), scion stem diameter (Diam-SC) and number of leaves (NL). Rootstock stem diameter was measured $5 \mathrm{~cm}$ above the base, while scion stem diameter was measured $3 \mathrm{~cm}$ over the grafting point.

The obtained data were subjected to analysis of variance by $F$ test at 0.05 and 0.01 probability levels. In case of significance, polynomial regression analysis with linear and quadratic models was carried out using the statistical software SISVAR-ESAL (FERREIRA, 2011).

\section{RESULTS AND DISCUSSION}

Based on the analysis of variance summary (Table 2), the levels of irrigation water salinity had significant effect on the internal $\mathrm{CO}_{2}$ concentration $(C i)$, stomatal conductance $(g s)$, transpiration $(E)$ and $\mathrm{CO}_{2}$ assimilation rate $(A)$ of West Indian cherry. However, $\mathrm{N}$ doses and the interaction between factors (SL x ND) did not have significant influence $(p>0.05)$ on any of the variables analyzed, at 130 days after transplanting. 
Table 2. Summary of analysis of variance for internal $\mathrm{CO}_{2}$ concentration $(\mathrm{Ci})$, stomatal conductance $(\mathrm{gs})$, transpiration $(E)$ and $\mathrm{CO}_{2}$ assimilation rate $(A)$ of grafted West Indian cherry irrigated with solutions of different salinity levels and nitrogen doses, at 130 days after transplanting.

\begin{tabular}{llllll}
\hline \multirow{2}{*}{ Source of variation } & \multirow{2}{*}{$\mathrm{DF}$} & \multicolumn{3}{l}{ Mean squares } & \multicolumn{3}{l}{} \\
\cline { 3 - 6 } & & $C i$ & $g s$ & $E$ & $A$ \\
\hline Saline levels (SL) & 4 & $46924.87^{* *}$ & $0.26^{* *}$ & $1.86^{* *}$ & $98.18^{* * *}$ \\
$\quad$ Linear regression & 1 & $181818.67^{* *}$ & $0.61^{* *}$ & $6.46^{* *}$ & $349.52^{* *}$ \\
Quadratic regression & 1 & $1331.72^{\text {ns }}$ & $0.33^{*}$ & $0.86^{* *}$ & $32.68^{*}$ \\
N doses (ND) & 3 & $2915.21^{\text {ns }}$ & $0.03^{\text {ns }}$ & $0.03^{\text {ns }}$ & $0.34^{\text {ns }}$ \\
Linear regression & 1 & $2494.08^{\text {ns }}$ & $0.04^{\text {ns }}$ & $0.07^{\text {ns }}$ & $0.72^{\text {ns }}$ \\
Quadratic regression & 1 & $1570.81^{\text {ns }}$ & $0.008^{\text {ns }}$ & $0.001^{\text {ns }}$ & $0.40^{\text {ns }}$ \\
Interaction (SL x ND) & 12 & $2298.23^{\text {ns }}$ & $0.04^{\text {ns }}$ & $0.06^{\text {ns }}$ & $4.08^{\text {ns }}$ \\
Blocks & 2 & $10837.91^{\text {ns }}$ & $0.03^{\text {ns }}$ & $0.007^{\text {ns }}$ & $12.01^{\text {ns }}$ \\
CV $(\%)$ & & 16.25 & 14.49 & 11.14 & 11.04 \\
\hline
\end{tabular}

$\mathrm{ns},{ }^{* *}, *$ respectively not significant, significant at $\mathrm{p}<0.01$ and $\mathrm{p}<0.05$; DF - Degree of freedom; CV -Coefficient of variation;

Increasing irrigation water salinity led to linear increment in the internal $\mathrm{CO}_{2}$ concentration of West Indian cherry, $28.23 \%$ per unit increase in $\mathrm{ECw}$ according to the regression equation (Figure 1A). Comparing plants irrigated with $4.0 \mathrm{dS} \mathrm{m}^{-1}$ water with those subjected to the lowest salinity level $\left(0.8 \mathrm{dS} \mathrm{m} \mathrm{m}^{-1}\right)$, internal $\mathrm{CO}_{2}$ concentration increased by $155.70 \mathrm{~mol} \mathrm{H}_{2} \mathrm{O} \mathrm{m}^{-2} \mathrm{~s}^{-1}$. Thus, increase in the intracellular carbon concentration in West Indian cherry (Figure 1A) may be associated with the reduction in the activity of enzymes involved in the $\mathrm{CO}_{2}$ fixation process, resulting from the stress caused by the excess salts in the water and/or soil (MACHADO et al., 1999). Nevertheless, increment in $\mathrm{Ci}$ is an indication that carbon dioxide was available for photosynthesis, i.e., there were no stomatal limitations (CHAVES et al., 2009). Sá et al. (2017) observed that West Indian cherry plants irrigated with saline waters (ECw: 0.6 to $3.8 \mathrm{dS} \mathrm{m}^{-1}$ ) showed lower $\mathrm{CO}_{2}$ assimilation rate and, according to the authors, it was caused by the reduction in stomatal conductance, a fact also observed in the present study.

West Indian cherry stomatal conductance was negatively affected by irrigation water salinity at 130 DAT and, according to the regression equation (Figure 1B), plants cultivated with $0.8 \mathrm{dS}$ $\mathrm{m}^{-1}$ water showed the highest $g s\left(0.085 \mathrm{~mol} \mathrm{H}_{2} \mathrm{O} \mathrm{m}^{-2}\right.$ $\left.\mathrm{s}^{-1}\right)$, which decreased from this point on. An estimated minimum of $0.030 \mathrm{~mol} \mathrm{H}_{2} \mathrm{O} \mathrm{m}^{-2} \mathrm{~s}^{-1}$ was found in West Indian cherry plants subjected to the highest salinity $\left(4.0 \mathrm{dS} \mathrm{m}^{-1}\right)$, which corresponded to a reduction of $0.055 \mathrm{~mol} \mathrm{H}_{2} \mathrm{O} \mathrm{m}^{-2} \mathrm{~s}^{-1}$ in comparison to those irrigated with $\mathrm{ECw}$ of $0.8 \mathrm{dS} \mathrm{m}^{-1}$.
Reduction in stomatal conductance (Figure $1 B$ ) in West Indian cherry plants cultivated with solutions of high salt concentration is due to a gradual stomatal closure and maintenance of lower leaf transpiration rate (Figure 1C), which is possibly a strategy to minimize the excessive dehydration of guard cells, due to the delay between water absorption and transpiration rates, or a consequence of the water imbalance in leaf epidermis (RIBEIRO et al., 2009). When $g s$ decreases, $\mathrm{CO}_{2}$ inflow to the substomatal cavity is limited (DALLAGNOL et al., 2011), consequently leading to reductions in the photosynthetic activity and leaf transpiration.

As observed for stomatal conductance (Figure 1B), leaf transpiration in West Indian cherry was significantly influenced by irrigation with salinity levels. According to the regression equation (Figure 1C), plants subjected to the lowest $\mathrm{ECw}$ level $\left(0.8 \mathrm{dS} \mathrm{m}^{-1}\right)$ showed highest $E(1.34 \mathrm{mmol}$ $\mathrm{H}_{2} \mathrm{O} \mathrm{m}^{-2} \mathrm{~s}^{-1}$ ), surpassing by $0.99 \mathrm{mmol} \mathrm{H}_{2} \mathrm{O} \mathrm{m}^{-2} \mathrm{~s}^{-1}$ those irrigated with water of the highest salinity level $\left(4.0 \mathrm{dS} \mathrm{m}^{-1}\right)$. Reduction of leaf transpiration in plants grown under saline stress is usually attributed mostly to osmotic effects associated with the accumulation of salts in the soil, low capacity of osmotic adjustment and reduction in total water potential caused by the increase in salt concentration (SILVA et al., 2011). Reduction of leaf transpiration in plants subjected to saline stress was also observed by Silva et al. (2017), evaluating the effect of irrigation water salinity varying between 0.3 and 3.5 $\mathrm{dS} \mathrm{m}{ }^{-1}$ on the contents of photosynthetic pigments and leaf morpho-physiology of guava seedlings cv. 'Paluma'. 

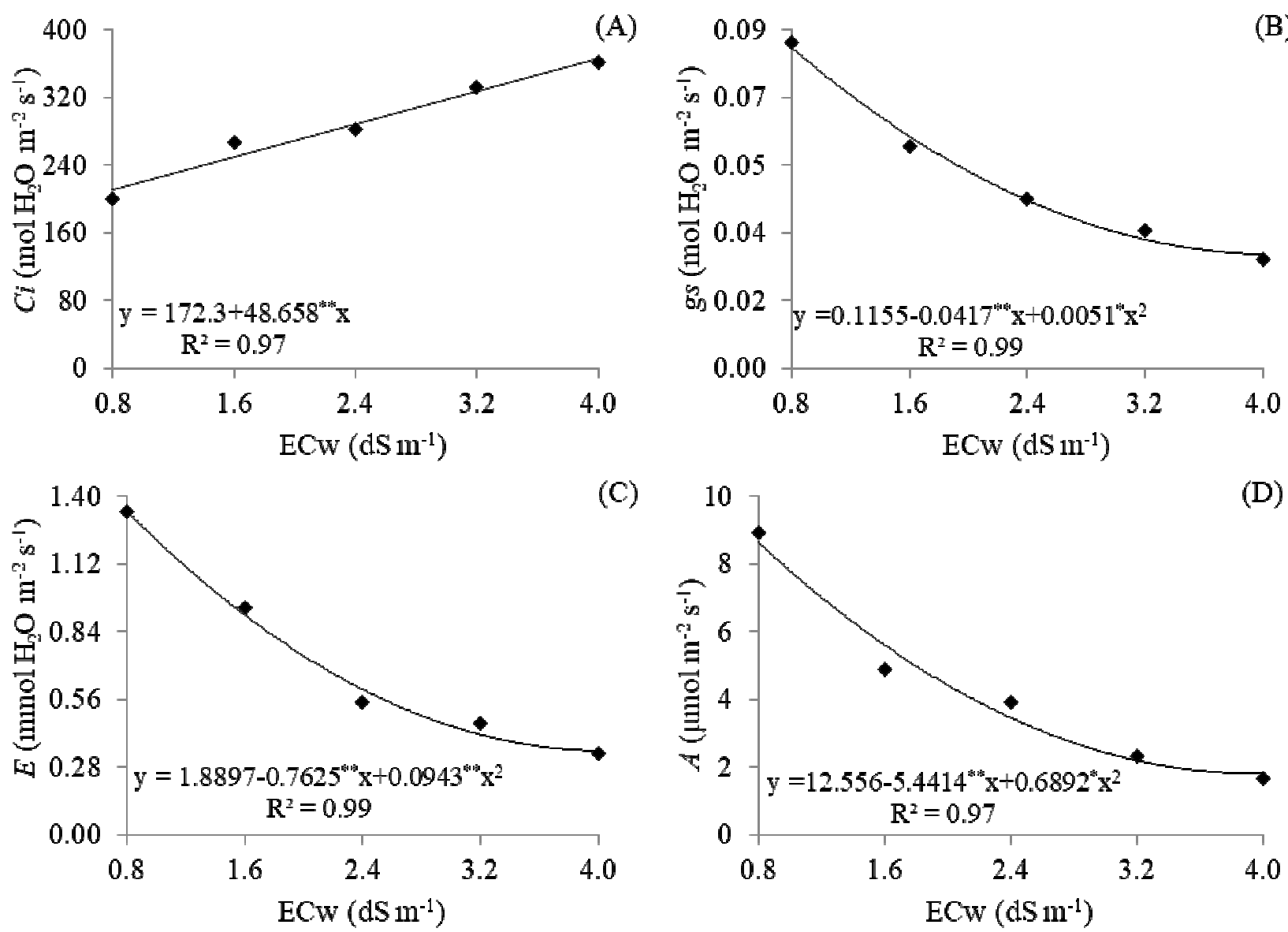

Figure 1. Internal $\mathrm{CO}_{2}$ concentration $(C i)$, stomatal conductance $(g s)$, transpiration $(E)$ and $\mathrm{CO}_{2}$ assimilation rate $(A)$ of grafted West Indian cherry, as a function of irrigation water electrical conductivity $\mathrm{ECw}$, at 130 days after transplanting.

In the present study $\mathrm{CO}_{2}$ assimilation rate also decreased significantly as ECw levels increased. According to the regression equation (Figure 1D), maximum estimated value of $A(8.64$

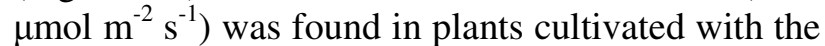
lowest salinity level $\left(0.8 \mathrm{dS} \mathrm{m}^{-1}\right)$, decreasing from this point on, while minimum of $1.81 \mu \mathrm{mol} \mathrm{m} \mathrm{m}^{-2} \mathrm{~s}^{-1}$ was found in plants under $\mathrm{ECW}$ of $4.0 \mathrm{dS} \mathrm{m} \mathrm{m}^{-1}$. In other words, there was a reduction of $6.83 \mu \mathrm{mol} \mathrm{m}^{-2}$ $\mathrm{s}^{-1}$ in the $\mathrm{CO}_{2}$ assimilation rate of West Indian cherry plants irrigated with $4.0 \mathrm{dS} \mathrm{m} \mathrm{m}^{-1}$ water, compared with those subjected to $0.8 \mathrm{dS} \mathrm{m}^{-1}$. Also, according to the data of $A$ (Figure 1D), the values obtained by West Indian cherry plants are not satisfactory because this crop has $\mathrm{C}_{3}$ photosynthetic metabolism, and its $\mathrm{CO}_{2}$ assimilation rate varies between 10 and $20 \mu \mathrm{mol} \mathrm{m} \mathrm{s}^{-2} \mathrm{~s}^{-1}$ (TAIZ; ZEIGER, 2013).

Despite the increment in $\mathrm{CO}_{2}$ availability (Figure 1A), its assimilation was limited in the plants. Such situation may have occurred due to partial stomatal closure, evidenced by the decrease in stomatal conductance (Figure 1B), associated with the osmotic effects of salinity, which can cause water stress on the plants. Sá et al. (2017) observed linear reduction in the $\mathrm{CO}_{2}$ assimilation rate of grafted West Indian cherry, at 45 days after transplanting, as a function of saline water irrigation (ECw: 0.6 to $3.8 \mathrm{dS} \mathrm{m}^{-1}$ ).

According to the summary of analysis of variance (Table 3), water salinity levels had significant effect on the maximum fluorescence $(\mathrm{Fm})$, variable fluorescence (Fv) and PSII quantum efficiency $(\mathrm{Fv} / \mathrm{Fm})$ of grafted West Indian cherry. Nitrogen doses had significant effect $(\mathrm{p}<0.05)$ only on maximum fluorescence. The interaction between water salinity levels and $\mathrm{N}$ doses did not significantly influence $(p>0.05)$ any of the variables evaluated, at $130 \mathrm{DAT}$. 
Table 3. Summary of analysis of variance for initial fluorescence (Fo), maximum fluorescence (Fm), variable fluorescence (Fv) and PSII quantum efficiency (Fv/Fm) of grafted West Indian cherry irrigated with water of different salinity levels and nitrogen doses, at 130 days after transplanting.

\begin{tabular}{|c|c|c|c|c|c|}
\hline \multirow{2}{*}{ Source of variation } & \multirow{2}{*}{ DF } & \multicolumn{4}{|c|}{ Mean squares } \\
\hline & & Fo & Fm & $\mathrm{Fv}$ & $\mathrm{Fv} / \mathrm{Fm}$ \\
\hline Saline levels (SL) & 4 & $412.62^{\text {ns }}$ & $412433.65^{* *}$ & $375804.39^{* *}$ & $0.28^{* * *}$ \\
\hline Linear regression & 1 & $316.87^{\mathrm{ns}}$ & $1629136.03^{* *}$ & $1380736.53^{* *}$ & $0.96^{* *}$ \\
\hline Quadratic regression & 1 & $966.72^{\text {ns }}$ & $36.21^{\mathrm{ns}}$ & $118296.21^{* *}$ & $0.15^{*}$ \\
\hline $\mathrm{N}$ doses (ND) & 3 & $5094.60^{\mathrm{ns}}$ & $1650.55^{\mathrm{ns}}$ & $1584.32^{\mathrm{ns}}$ & $0.01^{\mathrm{ns}}$ \\
\hline Linear regression & 1 & $2523.00^{\mathrm{ns}}$ & $18.75^{\mathrm{ns}}$ & $0.40^{\mathrm{ns}}$ & $0.001^{\mathrm{ns}}$ \\
\hline Quadratic regression & 1 & $1075.26^{\mathrm{ns}}$ & $1892.81^{\mathrm{ns}}$ & $4734.81^{\mathrm{ns}}$ & $0.02^{\mathrm{ns}}$ \\
\hline Interaction (SL x ND) & 12 & $6455.23^{\mathrm{ns}}$ & $13228.71^{*}$ & $1824.20^{\mathrm{ns}}$ & $0.01^{\mathrm{ns}}$ \\
\hline Blocks & 2 & $3024.23^{\mathrm{ns}}$ & $2356.31^{\mathrm{ns}}$ & $489.35^{\mathrm{ns}}$ & $0.007^{\mathrm{n}} \mathrm{s}$ \\
\hline CV (\%) & & 15.33 & 14.13 & 12.37 & 20.39 \\
\hline
\end{tabular}

Initial fluorescence $\left(\mathrm{F}_{\mathrm{o}}\right)$ represents the state in which the primary quinone electron acceptor of photosystem II (PSII) is fully oxidized and the PSII reaction center is open, situation preceding the activation of photochemical reactions (AZEVEDO NETO et al., 2011). Thus, based on the data presented in Table 3, the initial fluorescence of plants was not significantly affected $(p>0.05)$ by the studied factors, and its mean value was 170.16 electrons quantum ${ }^{-1}$. Therefore, it can be inferred that there were no alterations in the functional state of chloroplast thylakoid membranes, i.e., the PSII reaction centers of West Indian cherry were not compromised by saline water application and fertilization with increasing $\mathrm{N}$ doses. Additionally, it becomes evident that there was no reduction in the excitation energy transfer from the antenna complex to the reaction centers (BAKER, 2008).

Maximum fluorescence in West Indian cherry plants was significantly influenced by the interaction between water salinity levels and $\mathrm{N}$ doses. According to the regression equations (Figure 2A), West Indian cherry plants cultivated with $\mathrm{N}$ doses of 50, 75, 100 and $125 \mathrm{~g} \mathrm{plant}^{-1}$ showed linear reductions in Fm of 17.85, 18.15, 16.44 and $17.83 \%$ per unit increase in ECw. These values are equivalent to reductions of approximately 57.12, $58.08,52.08$ and $57.05 \%$ in the Fm of West Indian cherry plants irrigated with $4.0 \mathrm{dS} \mathrm{m} \mathrm{m}^{-1}$ water, in comparison to those subjected to ECw of $0.8 \mathrm{dS} \mathrm{m}^{-1}$. Reductions of Fm in West Indian cherry plants in response to the stress caused by the increment in water salinity evidence deficiencies in the photoreduction of quinone A (QA), which may be associated with the inactivation of PSII in thylakoid membranes, a situation that directly affects the electron flow between the photosystems (SILVA et al., 2006). Furthermore, the reduction in Fm may also be related to the full non-photochemical quenching of chlorophyll fluorescence and to the Stern-Volmer non-photochemical quenching (LICHTENTHALER et al., 2005).

Increased irrigation water salinity also negatively affected the variable fluorescence in West Indian cherry, at 130 DAT. According to the regression equation (Figure 2B), maximum (529.45 electrons quantum $\left.^{-1}\right)$ and minimum (100.39 electrons quantum ${ }^{-1}$ ) estimated values were obtained in plants subjected to the lowest $\left(0.8 \mathrm{dS} \mathrm{m}^{-1}\right)$ and highest $\left(4.0 \mathrm{dS} \mathrm{m}^{-1}\right)$ water salinity levels, respectively. In other words, Fm decreased by 429.06 electrons quantum ${ }^{-1}$ between plants irrigated with $4.0 \mathrm{dS} \mathrm{m}^{-1}$ water and those subjected to ECw of $0.8 \mathrm{dS} \mathrm{\textrm {m } ^ { - 1 }}$. Such situation may have directly influenced the photochemical activity in West Indian cherry leaves, since Fv indicates the plant's capacity to transfer energy from excited electrons of pigment molecules to the formation of the reducing agent NADPH, ATP and reduced ferredoxin (Fdr) and, consequently, higher capacity of $\mathrm{CO}_{2}$ assimilation in the biochemical phase of photosynthesis (BAKER, 2008).

For the PSII quantum efficiency (Figure 2C), 'West Indian cherry plants subjected to ECw of $4.0 \mathrm{dS} \mathrm{m}^{-1}$ showed value of 0.39 electrons quantum ${ }^{1}$, which corresponded to a reduction of 0.36 electrons quantum ${ }^{-1}$, in comparison to plants irrigated with the lowest salinity level $\left(0.8 \mathrm{dS} \mathrm{m}^{-1}\right)$. According to the regression equation (Figure 2C), the PSII quantum efficiency in West Indian cherry, measured by the Fv/Fm ratio, varied from 0.75 to 0.39 electrons quantum ${ }^{-1}$ between plants irrigated with ECw levels of 0.8 and $4.0 \mathrm{dS} \mathrm{m}^{-1}$, respectively. This situation demonstrates the occurrence of photoinhibitory damages to the PSII reaction centers because, when the photosynthetic apparatus remains 
unchanged, PSII quantum efficiency ranges from 0.75 and 0.85 electrons quantum ${ }^{-1}$ (REIS; CAMPOSTRINI, 2011). Therefore, the reduction observed in PSII may indicate major reduction in the primary electron acceptor (quinone A pool), which causes variation in the electron transfer rate between PSI and PSII, and consequently inhibition of photochemical activity (BAKER, 2008).
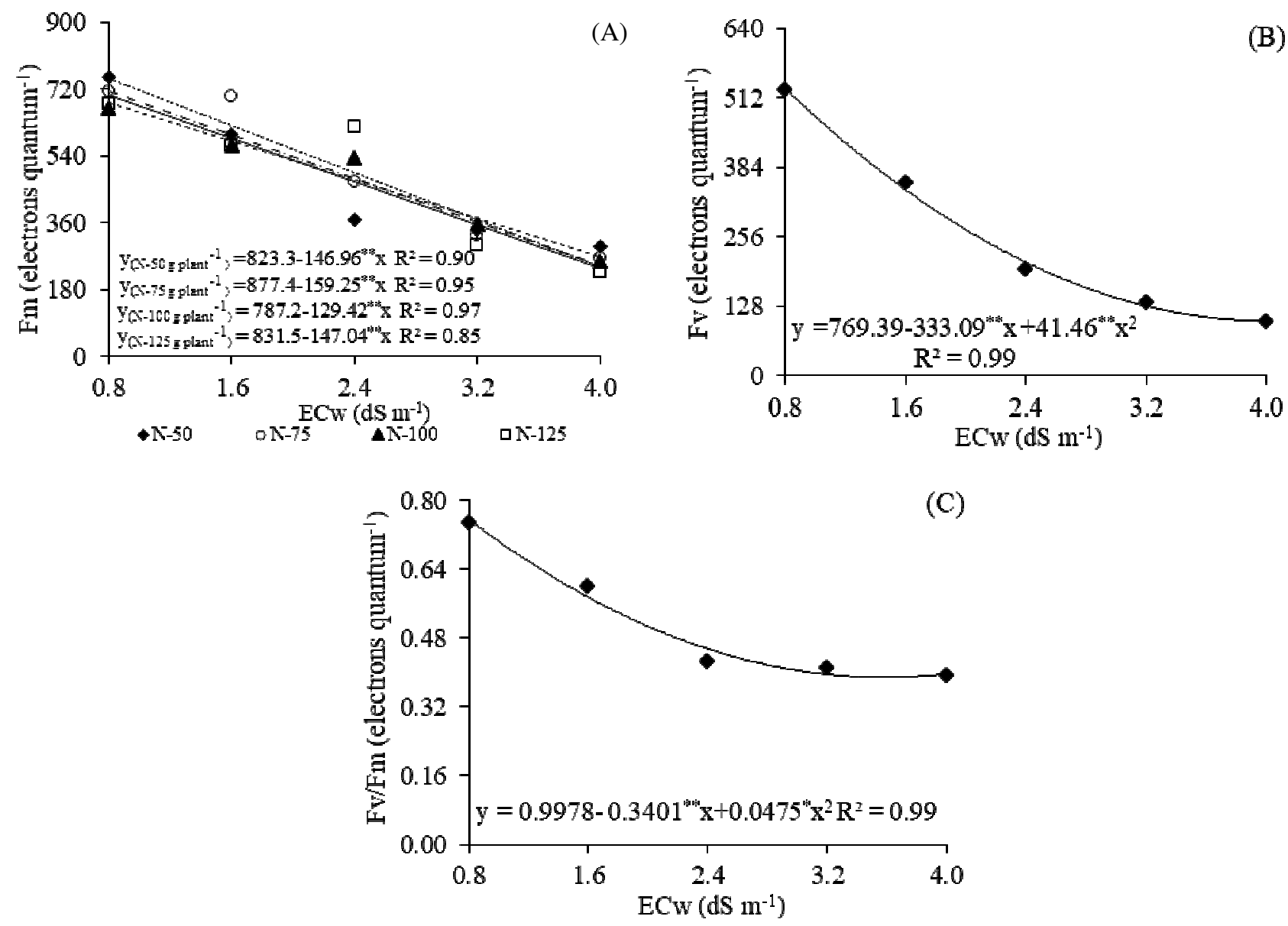

Figure 2. Maximum fluorescence - Fm as a function of the interaction between irrigation water electrical conductivity - ECw and nitrogen doses (A), variable fluorescence - Fv (B) and PSII quantum efficiency - Fv/Fm (C) of grafted West Indian cherry, irrigated with different levels of ECw, at 130 days after transplanting.

According to Table 4, which shows the results of the analysis of variance for rootstock stem diameter (Diam-RS), stem diameter at the grafting point (Diam-GP), scion stem diameter (Diam-SC) and number of leaves (NL) in grafted West Indian cherry, water salinity levels had significant effect on all variables studied. However, $\mathrm{N}$ doses and the interaction between factors (SL $x$ ND) did not significantly influence $(p>0.05)$ any of the variables, at 130 DAT.

Stem diameters of rootstock, grafting point and scion of West Indian cherry showed a similar response to that of gas exchanges data ( $g s, E$ and $A$ ) and, according to the regression equations (Figure 3 $\mathrm{A}, \mathrm{B}$ and $\mathrm{C}$ ), there were linear reductions of 9.64 , 5.88 and $4.16 \%$ per unit increase in $\mathrm{ECw}$, respectively. Comparing West Indian cherry plants subjected to $\mathrm{ECw}$ of $4.0 \mathrm{dS} \mathrm{m}^{-1}$ with those under $\mathrm{ECw}$ of $0.8 \mathrm{dS} \mathrm{m}^{-1}$, there were relative reductions of 2.49, 1.49 and $0.86 \mathrm{~mm}$ in Diam-RS, Diam-GP and Diam-SC, respectively. The inhibition of West Indian cherry growth induced by saline stress, evidenced by Diam-RS, Diam-GP and Diam-SC data, was possibly due to the osmotic effect of the dissolved salts, which reduce the osmotic potential of the soil solution. This situation results in greater energy demand by the plant to be able to absorb water from the soil and hampers water conduction to the cells, characterizing water stress. Consequently, the plant begins to have greater control over stomatal opening to avoid excessive water loss through transpiration (SOUZA et al., 2011). Additionally, the alterations in gas exchanges, evidenced by the reduction in $g s, E$ and $A$, may have 
contributed to decreasing West Indian cherry growth, since the efficiency in photosynthesis directly affects the accumulation of photoassimilates to be used for plant growth and/or development.

Table 4. Summary of analysis of variance for rootstock stem diameter (Diam-RS), stem diameter at the grafting point (Diam-GP), scion stem diameter (Diam-SC) and number of leaves (NL) of West Indian cherry irrigated with solutions of different water salinity and nitrogen doses, at 130 days after transplanting.

\begin{tabular}{|c|c|c|c|c|c|}
\hline \multirow{2}{*}{ Source of variation } & \multirow{2}{*}{ GL } & \multicolumn{4}{|c|}{ Mean squares } \\
\hline & & Diam-RS & Diam-GP & Diam-SC & NL \\
\hline Saline levels (SL) & 4 & $13.77^{* *}$ & $4.44^{*}$ & $1.47^{*}$ & $52457.43^{* *}$ \\
\hline Linear regression & 1 & $46.51^{* *}$ & $16.65^{* *}$ & $5.62^{*}$ & $183926.70^{* * *}$ \\
\hline Quadratic regression & 1 & $7.23^{\mathrm{ns}}$ & $0.64^{\mathrm{ns}}$ & $0.12^{\mathrm{ns}}$ & $24192.00^{\mathrm{ns}}$ \\
\hline $\mathrm{N}$ doses (ND) & 4 & $4.42^{\mathrm{ns}}$ & $1.33^{\mathrm{ns}}$ & $0.54^{\mathrm{ns}}$ & $192.24^{\mathrm{ns}}$ \\
\hline Linear regression & 1 & $0.12^{\mathrm{ns}}$ & $0.32^{\mathrm{ns}}$ & $0.20^{\mathrm{ns}}$ & $272.65^{\mathrm{ns}}$ \\
\hline Quadratic regression & 1 & $12.91^{\mathrm{ns}}$ & $3.44^{\mathrm{ns}}$ & $0.26^{\mathrm{ns}}$ & $216.60^{\mathrm{ns}}$ \\
\hline Interaction (SL x ND) & 15 & $4.08^{\mathrm{ns}}$ & $2.47^{\mathrm{ns}}$ & $1.36^{\mathrm{ns}}$ & $1465.25^{\mathrm{ns}}$ \\
\hline Blocks & 2 & $0.66^{\mathrm{ns}}$ & $0.24^{\mathrm{ns}}$ & $0.65^{\mathrm{ns}}$ & $2326.01^{\mathrm{ns}}$ \\
\hline $\mathrm{CV}(\%)$ & & 20.27 & 12.47 & 14.32 & 26.14 \\
\hline
\end{tabular}

$\mathrm{ns}, * *, *$ respectively not significant, significant at $\mathrm{p}<0.01$ and $\mathrm{p}<0.05$; DF - Degree of freedom; CV -Coefficient of variation.
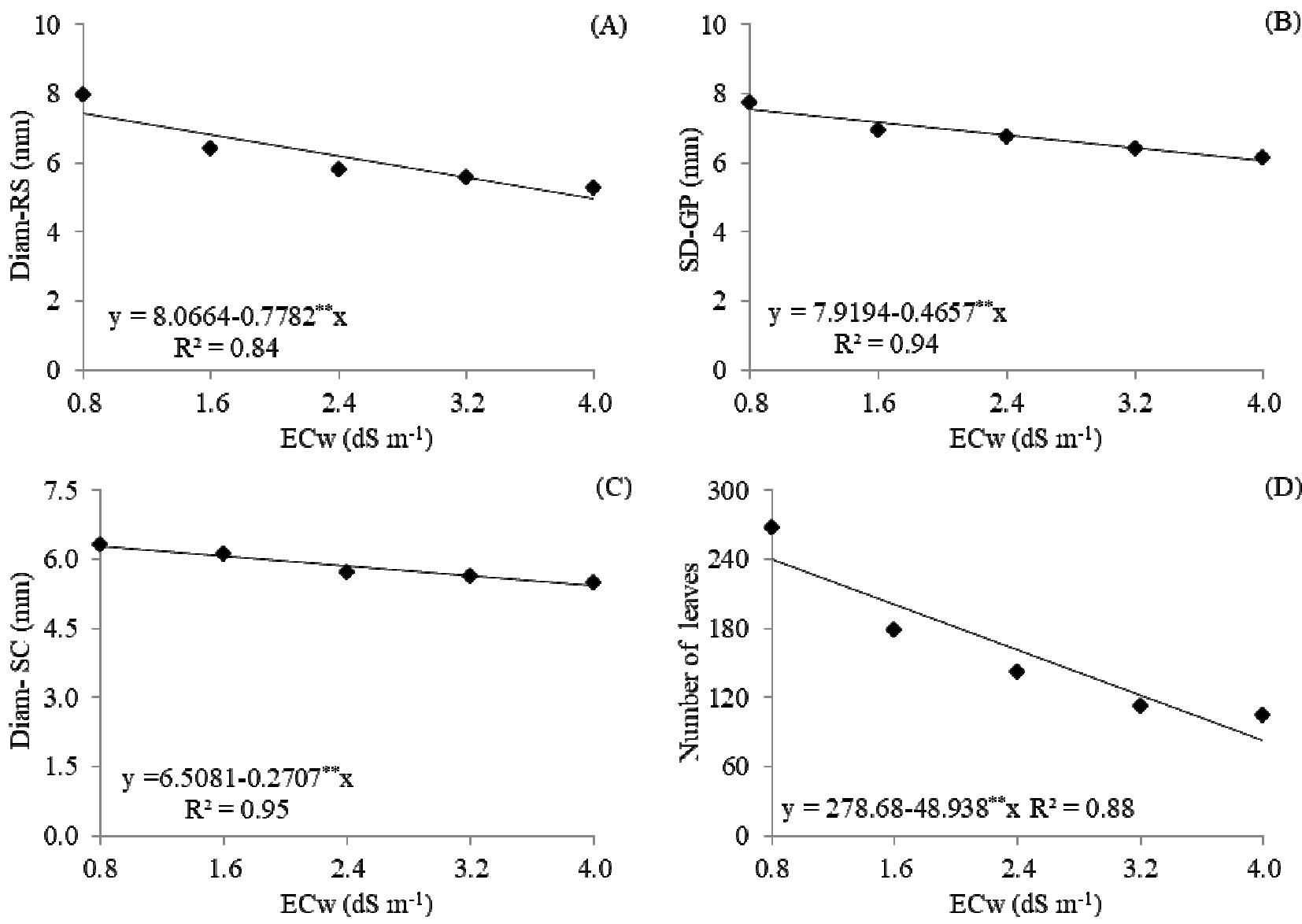

Figure 3. Rootstock stem diameter - Diam-RS (A), stem diameter at the grafting point - SD-GP (B), scion stem diameter - Diam-SC (C) and number of leaves - NL (D) of West Indian cherry, irrigated with solution of different salinity levels and nitrogen doses, at 130 days after transplanting.

The increase in the levels of irrigation water salinity substantially inhibited leaf production in
West Indian cherry plants and, according to the regression equations (Figure 3D), the data fitted best 
to a linear model, indicating that the increment in ECw led to reduction of $17.56 \%$ per unit increase in ECw. Lowest number of leaves (156.6 leaves) was estimated in plants irrigated with $4.0 \mathrm{dS} \mathrm{m}^{-1}$ water, i.e., reduction of approximately $56.19 \%$ in comparison to those irrigated with $0.8 \mathrm{dS} \mathrm{m}^{-1}$ water. The reduction in leaf production, evidenced by the decrease in the number of leaves in West Indian cherry (Figure 3D), can also be a consequence of the reduction in the osmotic potential, due to the high concentration of salts in the soil solution. Excess of salts in water and/or soil leads to alterations in various physiological and biochemical processes, such as respiration, photosynthesis, synthesis of proteins and metabolism of lipids, which may result in serious damages to plant growth and development (ESTEVES; SUZUKI, 2008).

The reduction in the number of leaves in West Indian cherry plants can be considered as an important adaptive mechanism to maintain satisfactory water absorption because, under such conditions, there is a reduction in transpiration and, consequently, decrease in the transport of $\mathrm{Na}^{+}$and $\mathrm{Cl}^{-}$ions through the xylem and maintenance of high water potential in the plant (OLIVEIRA et al., 2011). Souza et al. (2016) in a study evaluating the growth of guava during rootstock production, as a function of irrigation with different $\mathrm{ECw}$ levels (0.3 to $3.5 \mathrm{dS} \mathrm{m}^{-1}$ ), found that the number of leaves was not significantly influenced by water salinity.

\section{CONCLUSIONS}

Gas exchanges, chlorophyll $a$ fluorescence and growth of 'West Indian cherry are compromised by saline water irrigation, regardless of $N$ fertilization.

Use of saline waters with electrical conductivity higher than $0.8 \mathrm{dS} \mathrm{m}^{-1}$ causes damages to the photosystem II reaction centers of West Indian cherry.

Nitrogen doses did not mitigate the deleterious effects caused by irrigation water salinity on photosynthesis, photochemical efficiency and growth of West Indian cherry, at 130 days after transplanting.

\section{ACKNOWLEDGMENTS}

To the National Program of Post-Doctorate (PNPD/CAPES/UFCG), for granting the scholarship to the first author and to the National Institute of Science and Technology in Salinity - INCTSal, for funding the project.

RESUMO: Na região semiárida do Nordeste brasileiro, a salinidade da água é um dos principais fatores abióticos que restringem o crescimento e o desenvolvimento das culturas. Contudo, diante do quadro de escassez hídrica que afeta esta região, a utilização de águas com teores salinos de moderado a alto, faz-se necessário na irrigação das culturas. Desse modo, a geração de tecnologias que permitam o uso de águas salinas, constitui uma alternativa essencial para o desenvolvimento agrícola desta região. Neste contexto, objetivou-se com este trabalho avaliar a fotossíntese, eficiência fotoquímica e o crescimento da aceroleira, em função da irrigação com águas salinas e adubação nitrogenada, na fase pós-enxertia. O experimento foi conduzido em lisímetros de drenagem sob condições de casa-de-vegetação, utilizando-se um Neossolo Regolítico Eutrófico típico de textura franco-arenosa, no município de Campina Grande-PB. Os tratamentos foram constituídos da combinação entre cinco níveis de condutividade elétrica da água - CEa $(0,8 ; 1,6 ; 2,4 ; 3,2$ e $\left.4,0 \mathrm{dS} \mathrm{m}^{-1}\right)$ e quatro doses de nitrogênio - DN (50; 75; 100 e $125 \mathrm{~g}_{\text {de N }}$ planta $^{-1}$ por ano), distribuído no delineamento de blocos casualizados, com 3 repetições. As trocas gasosas, a fluorescência da clorofila $a$ e o crescimento da aceroleira foram comprometidos pela irrigação com águas salinas, independentemente da adubação com nitrogênio. A irrigação com CEa superior a $0,8 \mathrm{dS} \mathrm{m}^{-1}$ provocou danos nos centros de reação do fotossistema II da aceroleira. As doses de nitrogênio não mitigaram os efeitos deletérios ocasionados pela salinidade da água de irrigação sobre a fotossíntese, eficiência fotoquímica e o crescimento da aceroleira.

PALAVRA-CHAVE: Malpighia emarginata. Estresse salino. Nitrogênio.

\section{REFERENCES}

ADRIANO, E.; LEONEL, S.; EVANGELISTA, R. M. Qualidade de fruto da aceroleira cv. Olivier em dois estádios de maturação. Revista Brasileira de Fruticultura, Jaboticabal, Volume Especial, n. 1, p. 541-545, 2011. http://dx.doi.org/10.1590/S0100-29452011000500073. 
AZEVEDO NETO, A. D. de; PEREIRA, P. P. A.; COSTA, D. P.; SANTOS, A. C. C. dos. Fluorescência da clorofila como uma ferramenta possível para seleção de tolerância à salinidade em girassol. Revista Ciência Agronômica, Fortaleza, v. 42, n. 4, p. 893-897, 2011. http://dx.doi.org/10.1590/S1806-66902011000400010.

BAKER, N. R. Chlorophyll fluorescence: a probe of photosynthesis in vivo. Annual Reviews of Plant Biology, Boca Raton, v. 59, n. 1, p. 89-113, 2008. http://dx.doi.org/10.1146/annurev. arplant.59.032607.092759.

BARHOUMI, Z; ATIA, A.; RABHI, M.; DJEBALL, W.; ABDELLY, C.; SMAOUI, A. Nitrogen and NaCl salinity effects on the growth and nutrient acquisition of the grasses Aeluropus littoralis, Catapodium rigidum, and Brachypodium distachyum. Journal of Plant Nutrition and Soil Science, Weinheim, v. 173, n. 1, p. 149157, 2010. http://dx.doi.org/ 10.1002/jpln.200800113.

CALGARO, M.; BRAGA, M. B. A cultura da acerola. 3.ed. revista e ampliada. Brasília, DF: Embrapa, 2012.144 p. (Coleção Plantar; 69).

CAVALCANTI, F. J. de A. (Coord.). Recomendações de adubação para o Estado de Pernambuco: $2^{\mathrm{a}}$ aproximação. 2. ed. rev. Recife: IPA, 2008. 212 p.

CHAVARRIA, G.; DURIGON, M. R.; KLEIN, V. A.; KLEBER, H. Restrição fotossintética de plantas de soja sob variação de disponibilidade hídrica. Ciência Rural, Santa Maria, v. 45, n. 8, p. 1387-1393, 2015. http://dx.doi.org/10.1590/0103-8478cr20140705.

CHAVES, L. H. G.; GHEYI, H. R.; RIBEIRO, S. Consumo de água e eficiência do uso para cultivar de mamona Paraguaçu submetida à fertilização nitrogenada. Revista de Engenharia Ambiental, Espírito Santo do Pinhal, v. 8, n. 1, p. 126-133, 2011.

CHAVES, M. M.; FLEXAS, J.; PINHEIRO, C. Photosynthesis under drought and salt stress: regulation mechanisms from whole plant to cell. Annals of Botany, London, v. 103, n. 4, p. 551-560, 2009.

http://dx.doi.org/10.1093/aob/mcn125.

CLAESSEN, M. E. C. (Org.). Manual de métodos de análise de solo. 2. ed. rev. atual. Rio de Janeiro: Embrapa-CNPS, p.212, 1997. (Embrapa-CNPS. Documentos, 1).

DALlaGNOL, L. J.; RODRIGUES, F. A.; MARTINS, S. C. V.; CAVATTE, P. C.; DAMATTA, F. M. Alterations on rice leaf physiology during infection by Bipolaris oryzae. Australasian Plant Pathology, Clayton, v. 40, n. 4, p. 360-365, 2011. https://doi.org/10.1007/s13313-011-0048-8.

EPSTEIN, E.; BLOOM, A. J. Nutrição mineral de plantas: princípios e perspectivas. 2. ed. Trad. Londrina: Editora Planta, 2006. 392p.

ESASHIKA, T.; OLIVEIRA, L. A. DE; MOREIRA, F. W. Resposta da aceroleira a adubação orgânica, química e foliar num Latossolo da Amazônia Central. Revista de Ciências Agrárias, Lisboa, v. 36, n. 4, p. 399-410, 2013.

ESTEVES, B. S.; SUZUKI, M. S. Plants under effect of salinity. Oecologia Australis, Rio de Janeiro, v. 12, n. 4, p. 662-679, 2008.

FERREIRA, D. F. Sisvar: A computer statistical analysis system. Ciência e Agrotecnologia, Lavras, v. 35, n. 6, p. 1039-1042. 2011. http://dx.doi.org/10.1590/S1413-70542011000600001.

FREIRE, J. L. de O.; DIAS, T. J.; CAVALCANTE, L. F.; FERNANDES, P. D.; LIMA NETO, A. J. de. Rendimento quântico e trocas gasosas em maracujazeiro amarelo sob salinidade hídrica, biofertilização e cobertura morta. Revista Ciência Agronômica, Fortaleza, v. 45, n. 1, p. 82-91, 2014. http://dx.doi.org/10.1590/S1806-66902014000100011. 
Photosynthesis, photochemical...

LIMA, G. S. et al

GURGEL, M. T.; FERNANDES, P. D.; GHEYI, H. R.; SANTOS, F. J. S.; BEZERRA, I. L. Uso de águas salinas na produção de mudas enxertadas de aceroleira. Revista Caatinga, Mossoró, v. 20, n. 2, p. 16-23, 2007.

GURGEL, M. T.; FERNANDES, P. D.; GHEYI, H. R.; SANTOS, F. J. S.; BEZERRA, I. L.; NOBRE, R. G. Índices fisiológicos e de crescimento de um porta-enxerto de aceroleira sob estresse salino. Revista Brasileira de Engenharia Agrícola e Ambiental, Campina Grande, v. 7, n. 3, p. 451-456, 2003.

http://dx.doi.org/10.1590/S1415-43662003000300007.

LICHTENTHALER, H. K.; BUSCHMANN, C.; KNAPP, M. How to correctly determine the different chlorophyll fluorescence parameters and the chlorophyll fluorescence decrease ratio RFd of leaves with the PAM fluorometer. Photosynthetica, Prague, v. 43, n. 3, p. 379-393, 2005. https://doi.org/10.1007/s11099-0050062-6

LIMA, G. S. de; NOBRE, R. G.; GHEYI, H. R.; SOARES, L. A. dos A.; SILVA, A. O. Produção da mamoneira cultivada com águas salinas e doses de nitrogênio. Revista Ciência Agronômica, Fortaleza, v. 46, n. 1, p. 1-10, 2015. http://dx.doi.org/10.1590/S1806-66902015000100001.

MACHADO, E.C.; MEDINA, C.L.; GOMES, M.M.A. Teor de água no substrato de crescimento e fotossíntese em laranjeira "Valença". Bragantia, Campinas. v. 58, n. 2, p. 217-226, 1999. http://dx.doi.org/10.1590/S000687051999000200001.

MUNNS, R., TESTER, M. Mechanism of salinity tolerance. Annual Review of Plant Biology, Palo Alto, v. 59, n. 1, p. 651-681, 2008. http://dx.doi.org/10.1146/annurev.arplant. 59.032607.092911.

NEVES, A. L. R.; LACERDA, C. F. de; GUIMARÃES, F. V. A.; GOMES FILHO, E.; FEITOSA, D. R. C. Trocas gasosas e teores de minerais no feijão-de-corda irrigado com água salina em diferentes estádios. Revista Brasileira de Engenharia Agrícola e Ambiental, Campina Grande, v. 13, (Suplemento), p. 873-881, 2009. http://dx.doi.org/10.1590/S1415-43662009000700009.

NOBRE, R. G.; GHEYI, H. R.; SOARES, F. A. L.; CARDOSO, J. A. F. Produção de girassol sob estresse salino e adubação nitrogenada. Revista Brasileira de Ciência do Solo, Viçosa, v. 35, n. 3 929-937, 2011. http://dx.doi.org/10.1590/S0100-06832011000300027.

OLIVEIRA, F. A.; CARRILO, M. J. S.; MEDEIROS, J. F.; MARACÁ, P. B.; OLIVEIRA, M. K. T. Desempenho de cultivares de alface submetida a diferentes níveis de salinidade da água de irrigação. Revista Brasileira de Engenharia Agrícola e Ambiental, Campina Grande, v. 15, n. 8, p. 771-777, 2011. http://dx.doi.org/10.1590/S1415-43662011000800002.

REIS, F. O., CAMPOSTRINI, E. Microaspersão de água sobre a copa: um estudo relacionado às trocas gasosas e à eficiência fotoquímica em plantas de mamoeiro. Revista Brasileira Agrociência, Pelotas, v. 17, n. 1-4, p. 66-77, 2011.

RIBEIRO, R. V.; MACHADO, E. C.; SANTOS, M. G.; OLIVEIRA, R. F. Photosynthesis and water relations of well-watered orange plants as affected by winter and summer conditions. Photosynthetica, Prague, v. 47, n. 2, p. 215-222, 2009. https://doi.org/10.1007/s11099-009-0035-2.

RICHARDS, L. A. Diagnosis and improvement of saline and alkali soils. Washington: U. S. Department of Agriculture, 1954. 160p. (USDA, Agriculture Handbook, 60).

SÁ, F. V. da S.; GHEYI, H. R.; LIMA, G. S. de; PAIVA, E. P. de; FERNANDES, P. D.; MOREIRA, R. C. L.; SILVA, L. de A.; FERREIRA NETO, M. Water relations and gas exchanges of West Indian cherry under salt stress and nitrogen and phosphorus doses. Journal of Agricultural Science, Toronto, v. 9, n. 10; p. 168-177, 2017. https://doi.org/10.5539/ jas.v9n10p168. 
SILVA, E. C.; NOGUEIRA, R. J. M. C.; ARAÚJO, F. P.; MELO, N. F.; AZEVEDO NETO, A. D. Physiological responses to salt stress in young umbu plants. Environmental and Experimental Botany, Oxford, v. 63, n. 1-3, p. 147-157, 2008. https://doi.org/10.1016/j.envexpbot.2007.11.010.

SILVA, E. M. da; NOBRE, R. G.; SOUZA, L. de P.; PINHEIRO, F. W. A.; LIMA, G. S. de; GHEYI, H. R.; ALMEIDA, L. L. de S. Physiology of 'Paluma' guava under irrigation with saline water and nitrogen fertilization. Semina: Ciências Agrárias, Londrina, v. 38, n. 2, p. 623-634, 2017. http://dx.doi.org/10.5433/1679-0359.2017v38n2p623.

SILVA, F. L. B.; LACERDA, C. F.; SOUSA, G. G.; NEVES, A. L. R.; SILVA, G. L.; SOUSA, C. H. C. Interação entre salinidade e biofertilizante bovino na cultura do feijão-de-corda. Revista Brasileira de Engenharia Agrícola e Ambiental, Campina Grande, v. 15, n. 4, p. 383-389, 2011. http://dx.doi.org/10.1590/S1415-43662011000400009.

SILVA, M. M. P. da; VASQUEZ, H. M.; BRESSAN-SMITH, R.; SILVA, J. F. C. da; ERBESDOBLER, E. D.; ANDRADE JUNIOR, P. S. C. de. Eficiência fotoquímica de gramíneas forrageiras tropicais submetidas à deficiência hídrica. Revista Brasileira de Zootecnia, Viçosa, v. 35, n. 1, p. 67-74, 2006. http://dx.doi.org/10.1590/S1516-35982006000100008.

TAIZ, L.; ZEIGER, E. Fisiologia vegetal. 5. ed. Porto Alegre: Artmed, 2013. 918p. 